\title{
Insect Farming for Feed and Food Production from a Circular Business Model Perspective
}

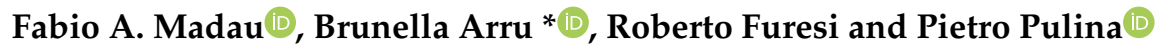 \\ Department of Agriculture, University of Sassari, SS 07100 Sassari, Italy; famadau@uniss.it (F.A.M.); \\ rfuresi@uniss.it (R.F.); ppulina@uniss.it (P.P.) \\ * Correspondence: brarru@uniss.it
}

Received: 30 April 2020; Accepted: 29 June 2020; Published: 4 July 2020

\begin{abstract}
The studies focused on the use of insects have outlined numerous reasons for using insects as food and feed as an important method to increase food opportunities for consumers. Insects have been emphasized as a food source with a low environmental impact due to the limited requirement for arable land and water, low ecological cost, and high-quality protein provision. In Europe and Western countries, insect farming is a growing business in which, however, some critical economic aspects must be recognized. The sector needs to be adequately promoted to rationally exploit the huge amount of potential. As such, the aim of this study was to analyze the recent research on economic aspects related to insect farming for feed and food production with the purpose of providing evidence of the critical economic points in this emerging sector. The focus was mainly oriented to understanding how insect farming can foster virtuous circular economic processes, specifically considering economic aspects on the basis of the limited literature currently available and the circular economic principles. A circular business model approach was proposed to address the entire insect-based feed and food supply chain from a circular economic perspective. In our opinion, the findings underline some economic research questions that need to be addressed in the near future, and the conceptual approach can be individualized to help increase cost- and eco-effectiveness from a circular economic perspective.
\end{abstract}

Keywords: circular economy; Europe; economic dimension; business model innovation; circular supply chain management

\section{Introduction}

The ever-increasing world population raises essential questions about our future capacity to produce and provide access to adequate food. The estimate of a necessary $70 \%$ increase in global food production by 2050 compared to 2009 to fulfil the additional need for food and feed [1] highlights the actual challenges that practitioners, researchers, and policymakers are facing. The increasing demand for animal-based protein is negatively impacting the environment in terms of greenhouse gas emissions, water, energy, and land usage [2]. Fears about global food security have arisen from food loss and waste across the entire supply chain, which accounts for about one-third of all food produced for human consumption (1.3 billion tons of edible food), having significant negative economic and environmental impacts [3].

Within the research focused on alternative protein sources in human and animal nutrition as well as food waste, edible insects are increasingly looking like a valid substitute to proteins of animal origin [4] and waste treatment [5-7]. Insects are efficient in converting food into protein [8]; depending on the species or processing method, they contain an average amount of protein (dry matter, DM) that varies between $50 \%$ and $82 \%$ [9-11], as well as being rich in nutrients such as calcium, iron, and zinc $[12,13]$. Insects are a food source with a low environmental impact due to, amongst others, the limited need for arable land and water, compared with livestock $[8,14]$, and low ecological cost (low 
greenhouse gas and carbon dioxide emissions) [14]. These features are particularly crucial for the aquaculture sector, which must respond to the growing world demand for fish and which needs to replace fishmeal with other high-protein feed [15].

With regards to the novelty of insect farming, despite the limited market data about insect powders, different advantages have been highlighted, especially for small-scale production: low investment, technology, and production area requirements; rapid breeding cycles; and few barriers to entry [13,16-18]. All these advantages are the basis of the increase in the global edible insect market, which is expected to reach USD 8 billion and a volume of 730,000 tons in 2030 [19]. Despite the size increase of the insect industry in the global market, and especially in Europe and the United States [20], this revolution in the economic development models of agri-food supply chains faces several challenges in overcoming political, legal, economic, social, and technological product- and process-specific barriers [5].

Particular attention is put on studies in European and Western countries, where insect farming still represents a challenge and where insect-based feed and food are far from being consolidated markets [21]. The European Union normative has only recently allowed introducing feeds derived from some insects into animal diets (EU Rer. 217/893). This regulation has permitted the use of processed animal proteins (PAPs) from insects in the diet of farmed fish limited to seven species (Hermetia illucens, Musca domestica, Tenebrio molitor, Alphitobius diaperinus, Acheta domesticus, Gryllodes sigillatus, and Gryllus assimilis). However, the use of insect PAPs to feed poultry and pigs is still banned within the European Union, unlike in China, South Korea, Kenya, Uganda, and Canada (related to Hermetia illucens in poultry feeding) [22-24].

European consumers, despite some differences between countries, tend to prefer eating ingredients of a given food in original form, and reluctance remains toward consuming insect-based food [25-28]. However, feed and food demands are increasing, including in Europe [29]; therefore, more attention has been paid to this sector by scholars.

Insects for feed and food have a place in the ecological economy that "investigates reciprocal barriers between natural and production systems, focusing on long-term environmental sustainability" [5] (p.39), providing an innovative strategy for the transition from the linear economy in which natural resources follow a cradle-to-grave flow, to a sustainable economic system that pursues the creation of a cradle-to-cradle production system [5,30]. Insect farming shows an inherent ability to recycle any sort of food and organic waste, beneficially affecting feed and food quality and productivity (with reference to other raw materials used for feeding insects). Given its nature, this kind of farming tends to minimize the use of water and other natural resources. In other words, processing edible insects for food and feed provides a natural missing link in designing a circular economy (CE) [12]. Using insects in innovative business models would environmentally, socially, and economically improve the performance of agri-food systems $[5,13,23]$.

As such, we reviewed the recent research on the economic aspects of insect farming for feed and food production. The purpose was to provide evidence of the main critical economic points in the scientific literature on this emerging sector and individuating an adequate economic approach to rationally exploit the possibilities of insect farming into the $\mathrm{CE}$ paradigm. The focus was understanding how insect farming can foster virtuous CE processes, specifically considering the economic aspects on the basis of the limited literature and the CE principles. In short, we aimed to provide an economic conceptual framework to steer the whole insect-based feed and food supply chain toward the CE paradigm and to underline some economic research questions that should be addressed in the near future, especially from a CE perspective. This theoretical framework was constructed within the circular business model (CBM), which should allow addressing the entire supply chain from a CE perspective. Specifically, circular supply chain management (CSCM) might be a strategy for creating new value and improving operative cost- and eco-effectiveness in part through insect farms, with upstream and downstream companies exploiting the inherent sector ability to generate virtuous circular processes. 
The remainder of this paper is structured as follows: Section 2 introduces the CE paradigm, with specific references to those approaches that appear more suitable for enhancing the insect feed and food sector; Section 3 briefly describes insect farming according to the scientific literature; Section 4 deals with insect farming from a circular economic perspective; Section 5 outlines the economic framework for addressing the entire insect feed and food supply chain toward a CE perspective to ensure a better cost- and eco-effectiveness; finally, some concluding remarks are provided in Section 6.

\section{Theoretical Circular Economy Concept}

The circular economy is gaining increased attention from academics, politicians, and practitioners. CE is "an idea and ideal" [31] (p. 218) to redirect the path of economic development and enable cyclical thinking toward creating a zero-waste economy [31-33]. Academic speeches about CE concepts are in the initial stage, and the literature is in its infancy, with many unexplored fields, differences in research communities, and holistic approaches missing [34]. The CE has been defined as an "umbrella concept" [33] under which there is no single definition [35]. In the mare magnum of the approach — cradle-to-cradle design [30], cleaner production [36], industrial ecology [37], industrial symbioses [38], laws of ecology [39], regenerative design [40], biomimicry [41], blue economy [42], and natural capitalism [43], to mention a few-and definitions, we particularly reference four definitions that provide diverse perspectives of CE analysis and are well suited to our aim [34]:

- "The CE conceives of a production and consumption system with minimal losses of materials and energy through extensive reuse, recycling, and recovery" [44] (p. 832);

- " $\quad \mathrm{CE}$ is an economic strategy that suggests innovative ways to transform the current predominantly linear system of consumption into a circular one while achieving economic sustainability with much-needed material savings" [45] (p. 343);

- "The CE model embraces innovative concepts, such as designing out waste and pursuing eco-effectiveness, instead of eco-efficiency" [46] (p. 621); and

- "A circular economy is a mode of economic development that aims to protect the environment and prevent pollution, thereby facilitating sustainable economic development" [47] (p. 506).

These different focuses on the CE allow consideration of the most important actors in turning waste into resources, a process achievable through a transition to a new business model based on resource efficiency that facilitates sustainable economic development.

CE calls for a "complete reform of the whole system of human activity, which includes both production processes and consumption activities" [48] (p. 5). The producers "will be central stakeholders in achieving an optimised, zero-waste production and distribution system" [49] (p. 549), since they can, and are called to, design products and business systems that reduce environmental impacts. Consumers, through their choices, can simultaneously support or hamper the successful transition to a CE [50].

The paradigm shift in the CE requires a complex and long socio-technical transition [51,52]. Socio-technical transitions theory [53], focused on how, why, and to what effect innovations permeate through society, is based on a multi-level perspective where the interactions between micro-(innovation niche), meso- (technological regime), and macro-level (socio-technical landscape) can produce a socio-technical transition. That is, a niche technology replaces the old technological regime, becoming the new dominant regime. This is only possible if (1) changes occur at the landscape level that create enough pressure upon the existing regime to destabilize it, and (2) an innovation niche, understood as a source of radical innovations, for example, in terms of price/performance improvements, is sufficiently developed [54].

Environmental and economic issues resulting from increasing global population and dwindling natural resources have given rise to circular niche innovations. In the Anthropocene landscape, the call for embracing CE thinking to reduce the impact of humanity on the environment and radically rebalance human-nature relations [55] is getting stronger, especially in the agriculture sector. Agriculture is the 
most essential practice for human survival but, responding to the increasing food demand and being subject to insecure procurement and the price volatility of resources, is become the main problem of this era [56], especially since "agricultural wastes have become the important pollution sources" [57] (p. 13). Therefore, promoting the development of new technologies to encourage the paradigm shift toward waste recycling is crucial [33].

In this context, firstly, companies must change their visions, as they often focus mainly on short-term goals, although they are often aware of the future economic potential opportunities derived from the introduction of $\mathrm{CE}$ innovations [51]. "CE is emerging as an economic strategy rather than a purely environmental strategy" [48] (p. 5) aimed at improving economic results while reducing the use of resources. The CE is a radical concept [55] that, according to the cradle-to-cradle design [30], creates waste-free technical loops since product design is based on the principle that the materials are nutrients that circulate in a closed-circuit metabolism.

Secondly, the rethinking of the ecological-economic system relationship has to shift from the "doing things right" strategy, which can mean "making things less bad" [6], to the "doing the right things" strategy, which may require extra effort but can lead to a "change of the story" $[37,58,59]$. In other words, CE should deal with eco-effectiveness, which aims to reconfigure how materials pass through industrial systems, creating regenerative industrial metabolisms that enable materials to maintain their status as resources (rather than eco-efficiency) based on the "minimizing the volume, velocity, and toxicity of the material flow system, but are incapable of altering its linear progression" [60]. Eco-effectiveness could be researched according to cost-effectiveness needs to ensure the economic sustainability of a given production system.

Thirdly, many scholars see sustainable development as the main objective of the CE and as an integral part of the sustainability agenda [61,62]. Sustainable Development Goal (SDG) 9 of the Agenda 2030 could be translated as the sustainable reconfiguration of industries. In the minds of the European Commission, a relationship exists between the CE and the SDGs, making special reference to SDG 12 (ensure sustainable consumption and production patterns) [63]. CE has been linked to other SDGs [64], although no adequate indicators exist for how the CE promotes social equity [65]. However, if we consider that the latter also encompasses inter-generational equity, the $\mathrm{CE}$, saving resources useful for the next generation, is well-matched with all sustainability dimensions.

\section{Insect Farming: Current Status}

For years, many kinds of insects have been part of the diet of some farmed animals (e.g., chickens, pigs, and especially fish) due to the provision of high-quality protein. Human consumption of insect-based food is becoming an increasingly popular alternative source of proteins. It is estimated that 2 billion people currently consume insects or insect-based food [66]. Insect consumption occurs in more than 110 countries, even if the distribution is still concentrated in tropical latitudes where entomophagy is an ancestral practice in many areas. However, consumption is tending to increase in Western countries, despite most people still rejecting insects as food.

Edible insects' production occurs through three methods: wild harvesting, semi-domestication, and farming. According to Yen [67], harvested insects represent $92 \%$ of the total world insect supply, and semi-domesticated insects account for $6 \%$. This means that only $2 \%$ of supplied insects are currently farmed if we only consider those intended directly for human consumption.

van Huis and Oonincx [21] affirmed that edible insects are traditionally harvested in tropical countries, and this practice plays important economic and social roles. These insects are marketable, and this market represents a source of familiar income (often insect prices are higher than those related to alternative meat products).

Insect farming is a recent method of producing edible insects, especially in developed countries $[14,21,68]$. Insects are cultivated in captivity, and each rearing step is controlled (e.g., living conditions, diet, and food quality). Per van Huis [69], who provided further information about farming 
techniques, benefits, and drawbacks, farming is undoubtedly the most productive and efficient method for producing insects.

Some technical and management advantages are attained by breeding insects compared with most livestock alternatives for producing natural proteins. Wilson [70], Mlcek et al. [71], and Govorushko [13] summarized the benefits linked to this sort of farming:

- Insect farming needs less space than traditional livestock. It requires limited investment costs (per unit of protein produced);

- Breeding is solely practiced with simple technology. For further information about these technologies, see Oonincx and de Boer [14], Cortes Ortiz et al. [72], and Dossey et al. [73];

- This kind of farming allows for fast returns on investment and high financial returns; and

- The management of this farming is simple and does not require in-depth training.

Govorushko [13] reported that insect farming for feed and food production has been developed worldwide, and it is becoming an important business not only in tropical countries [20]. According to Derrien and Boccuni [74], many companies are dedicated to this activity, and some European countries, such as the Netherlands and France, are the world leaders in this sector [13]. In Europe and other Western countries, production is mainly focused on feed for domestic animals, whereas in tropical countries, insects are predominantly farmed for human consumption.

Insect farming for the feed industry has dramatically increased in the last decades due to the inherent ability of insects to act as substitutes for traditional feeds in many livestock and fish practices. The embedded energy derived from organic matter used to feed insects is efficiently converted into high-value edible proteins aimed to feed livestock and fish (and humans) $[75,76]$. Insect meat is very rich in vitamins, fat, and minerals [4,77]. The result is the rapid worldwide increase of the insect feed market that, according to Mordor Intelligence [78], was valued at USD 687.8 million in 2018, with annual growth forecasts of $12 \%$, reaching a value of USD 1396.4 million by 2024 . In particular, as of 2018, the insect feed market was dominated by the Asia-Pacific in response to the increase in meat consumption; Europe is expected to be the fastest-growing market in the next few years. Analyzing the insect feed market by animal type, aquaculture is the primary buyer ( $51 \%$ of shares), whereas the market share analysis shows highly fragmented purchasers, with some leading companies (AlltechCoppens, Enterra Feed Corporation, Ynsect, Agroprotein, and Enviroflight).

The insect feed supply is characterized by a double track. On the first track, large multinationals are increasingly appearing on the market; on the second track are micro-enterprises that can economically satisfactorily produce insects due to the use of simple technologies and exploiting the possibilities offered at the local level, especially in the field of aquaculture. This means that at the global level, many companies are involved in the production of insect feed, of which few are involved in animal feed production, being concentrated only on insect feed production. In this context, significant market opportunities and challenges exist for the insect feed sector, such as commercial-scale production, high quality standards, the huge quantity required, low environmental impacts, and the need for competitive prices. Coping with these challenges would increase the market share of insect feed even more.

Despite the increasing relevance of the sector and the management peculiarities, few studies have focused on the economic aspects of insect farming (both for feed and food production) in our knowledge. Gahukar [79] attempted to evaluate the economic convenience of insect cultivation concerning other meat production alternatives based on information reported in the scientific literature. Gahukar highlighted that insect farming is currently not cheap. The main cost is represented by the raw materials used for feeding insects and, today, the price related to the formulated feed is quite high (e.g., USD 18 for $25 \mathrm{~kg}$ of feed for cricket breeding). However, neither Gahukar [79] nor Chia et al. [23] nor others has estimated or reported costs and profitability related to insect farming.

The economic literature on the convenience of introducing insect meals into the animal diet is lacking. Onsongo et al. [80] provided information on the price competitiveness of feed derived from 
insect farming. Specifically, the findings showed that feeds based on a fly meal, i.e., black soldier fly (Hermetia illucens) and house fly (Musca domestica), are cheaper than fishmeal (in this case, used for boilers growth). A $25 \%$ higher return on livestock investment was estimated by switching from traditional meals (fish and soybean meal) toward an insect-based meal in the sector due to higher feed conversion related to insect meal and the advantageous price of the raw materials (the price of insect meal is about $71 \%$ that of fishmeal). The authors outlined some policy implications in the study, suggesting that fostering insect mass production farming would drive different economic benefits (e.g., income generation and job creation) in developing countries.

Arru et al. [15] found that use of insect meals in aquaculture, specifically meals derived from the yellow mealworm (Tenebrio molitor) in European seabass farming, is inconvenient compared to the most used feed (fishmeal). The study was conducted in Italy where insect meal price, as well as in Europe, is higher than that of fishmeal. However, the authors underlined that a partial introduction of insect meals to the fish diet should be increasingly promoted to improve the sustainability of the sector (not only the economic dimension) under a CE approach.

Finally, another variable that might affect the economic performance of insect farms and downstream activities (e.g., aquaculture) is the insect-based food market. Scientific literature around the world has focused on the issue of eating insect-based foods or meat fed with insect proteins. Especially in recent years, scientific interest in the topic has also been growing in Western economies, with increased awareness of promoting models and styles of sustainable consumption. Concerning European countries, the introduction of insects to diets is typically regarded with disgust and skepticism $[4,13,81-88]$, and this may negatively affect the economic performance of the insect feed and food sector. However, the importance of insects as food in these realities is being increasingly considered in scientific and institutional debates.

\section{A CE Perspective on Insect Farming}

The many studies on insect farming in the recent literature are useful for better understanding the characteristics, novelties, and the main challenges related to this sector. However, literature that considers economic aspects, suggesting paths to take to address the main problems with insect farming, is lacking. Among others, two important research questions that need to be addressed are:

(1) Cost-effectiveness and profitability of insect farming. Research has highlighted that the cost-effectiveness of insect farming is far from adequate within many European and developed realities. It is not clear how and how much farms can improve their performance considering that production processes are different from each other, (ii) operational scale significantly varies among farms (production system varies from extra-small farms to multinational companies), (iii) a large number of insect species are reared, and (iv) legislation often restricts these sorts of farmers.

(2) Insect farms organization. The published studies lack information about how insect farms are organized. However, this is a crucial issue that should be further investigated to understand how the cost-effectiveness and profitability of this sort of business can be increased.

It is a common opinion that production cost tends to remarkably decrease from a CE perspective, with positive implications on farm organization $[22,79,81]$. The rationale underlines that insects can reduce natural resources consumption and are more efficient in converting energy used in proteins, especially if farming is aimed at recycling some resources. Firstly, insects obtain the water they need directly by food. This means that they naturally tend to consume much less water than other animal livestock. Secondly, the feed conversion ratio is high in insect breeding, therefore feed requirement is low $[89,90]$. Finally, insects show an aptitude for eating organic biomass and converting it into proteins [5]. In this sense, insect farming represents a typical example of a CE process. This sort of farming can be easily practiced through recycling food and organic waste without having remarkable implications on productivity and quality. Saprophagous insects can feed on any organic matter, and 
more studies have confirmed the ability to use organic waste to recycle nutrients and to produce useful raw materials for feeding other farmed animals or for human consumption [5].

Most of these studies showed that this recycling attitude does not compromise production compared to other alternative feed used and has positive effects on the biosphere. The increase in animal protein production has driven overexploitation of natural resources, resulting in a high level of degradation, especially in tropical countries [91,92]. In the case of fish production, both in fisheries and in aquaculture, this critical point has become even more worrying because fishmeal is the main base adopted for the fish diet; therefore, overexploitation of marine resources is an increasing issue on the planetary scale [15].

As such, the use of feed derived from bio-products might dramatically limit additional crop production. The additional feed savings mean that low water and energy requirements would be used for growing feed, having other beneficial implications on the use of land (for producing feed), waste disposal (bio-products are used for feed), and greenhouse gas emissions [69]. Premalatha et al. [93] underlined a contradiction: a huge economic effort is made every year to save crops around the world by killing insects when crops contain no more than $14 \%$ plant protein and insects contain up to $75 \%$ high-quality animal protein. Behind this contradiction lies a truth that can create interesting opportunities if there is a willingness to rethink the production systems aimed at food production and enhance the dynamics of the CE. More generally, sustainable and circular insect farming can contribute to reducing the pressure on natural resources.

Based on these issues, Gahukar [79] demonstrated that the use of water, land, and other natural resources is largely lower in insect farming than in other meat production practices. Adopting virtuous and rational farming, therefore, in future insect farming would be much cheaper due to the ability to directly and indirectly save land, water, energy, and feed, and achieving high productivity with economic benefits for farms compared with other meat producers.

The CE perspective appears interesting as the main insect species suited for recycling waste are among those commonly used to produce animal feed [22,94].

A recent attempt to collocate insect farming into the $\mathrm{CE}$ framework and provide evidence of economic aspects related to this activity was made in a review by Chia et al. [23]. Considering the possibility of using organic waste for feeding farmed fly larvae and using the study by Roffeis et al. [95] as a reference, the authors stated that the main cost item is due to investments in infrastructure such as containers and space. However, this cost is generally minor compared to that for other livestock practices. Other costs include labor, electricity, water, and feed substrates for the larvae. This evidence confirms the low economic burden linked to the breeding of insects, even if they report experiences in a well-known reality (West Africa) for specific farming (fly larvae) and a specific target (feed market).

In the process of replacement of the traditional linear model of growth with the CE model, legislative constraints are of paramount importance concerning insect farming and consumption. In Europe, the principles of the CE find application in some steering policy documents of the European Commission. In 2014, with the document "Towards a circular economy: A zero waste programme for Europe", the European Union (EU) presented an integrated approach to the value chain from product production to consumer action. In 2018, the European Parliament introduced the new "Circular Economy Package", which aims to "close the loop" of the lifecycles of product through greater recycling and reuse. In addition to the ambitious EU recycling and landfill reduction targets, this package indicates which foods that are no longer intended for human consumption can be used in feed production, excluding, unlike other regulations, the use of catering or animal waste [96].

From a worldwide perspective, to shift the world onto a sustainable and resilient path, in September 2015, the United Nations adopted the 2030 Agenda for Sustainable Development aimed at joint action to achieve food security and improved nutrition, promote sustainable agriculture, and fight climate change. Numerous Sustainable Development Goals (SDGs) are relevant to the field of insects and directly connected to the CE framework $[23,24]$. 
The main ones are to end poverty (SDG 1) and hunger (SDG 2), as "with minimal inputs, resource-poor people can set up small insect farms to produce for themselves or the local market hence reducing poverty and hunger" [23] (p. 27). With regards to SDG 13 (climate action), insects are an essential alternative to livestock production, helping to achieve the greenhouse gas reduction target. Increasing insect-feed production could positively affect biodiversity, providing a substitute for fishmeal and countering forest conversion into agricultural land, in alignment with SDGs 14 and 15 and the CE pillar of the ecosystem approach, which involves thinking holistically, paying attention to the entire system, and considering the cause-effect relationships between the different components, starting from saving resources, including natural resources.

To achieve these goals, sustainable production and consumption models must be pursued according to SDG 12. When using organic waste streams (i.e., manure and crop residues) is possible, a sustainable CE production pattern is feed. The use of the waste stream from insect production as a fertilizer in agriculture [97] adds to the CE models of insects for feed. Among other environmental pillars, SDG 6 (clean water and sanitation) also has a strong relationship with CE practice [64] due to its direct impact on food production [23]. Previous studies demonstrated the important role of insects in reaching this goal [98]. The CE is directly linked to SDG 8 as well (decent work and economic growth). In this context, commercial insect farming is viewed as a nascent sector with high importance in terms of economic growth and employment opportunities [23].

Since the adoption of Agenda 2030, the EU has played an active role in achieving the three pillars of sustainability, along with the ongoing reform of the Common Agricultural Policy (CAP). This is a policy that has a large impact on both the consumption and production of food [99], which aims to support agricultural development in an environmentally, socially, and economically desirable direction. On 29 November 2017, the EC published a new communication on the future of food and agriculture, in which it defines a new set of priorities, including the CE. The new Circular Economy Action presents measures focused on the sectors that use the most resources and where the potential for circularity is high, such as packaging, food, water, and nutrients. Previous studies demonstrated the role of insects in these sectors $[13,22]$.

\section{A Circular Business Model Perspective}

Given these considerations, including those outlined in Section 2, the main challenge concerning the adoption of a CE approach is which model needs to be promoted for incorporating the CE from an economic perspective. As reported above, the $\mathrm{CE}$ should be mainly considered an economic strategy and operate from an eco-effectiveness rather than an eco-efficiency view [48]. In this sense, CE thinking calls for losing the short-term business goals; the transition to a CE implies a whole-system change through radical technological and non-technological innovations throughout the entire structure industrial system and business models [46]. Specifically, to ensure that innovations are successful in the market and transition the whole system toward the CE paradigm, companies must adopt a business model innovation suited for CE.

Business model innovation (BMI) is a novel method of creating and capturing value, through "a change of one or multiple components in the business model" [10] (p. 253). The circular business model (CBM) can, therefore, be interpreted as "a business model in which the conceptual logic for value creation is based on utilizing economic value retained in products after use in the production of new offerings" [100] (p. 112). The CBM aim is to satisfy customers' needs, creating value for them and solving their problems related to rational and not rational motives of their behavior [29] at a cost lower than the value of the solved problem [101,102]. CBM creates commercial value capitalizing on the economic and environmental value embedded in products [103]. It incorporates "elements that slow, narrow, and close resource loops, so that the resource input into the organisation and its value network is decreased and waste and emission leakage out of the system is minimized" [104] (p. 713). Therefore, CBM offers and acquires value for companies and society in the whole by contributing to environmental safeguarding [105]. 
As the company's opportunity to create new value is strictly related to the supply chain, circular supply chain management (CSCM) plays a large role in the organization business model. CSCM is understood as "the configuration and coordination of the supply chain to close, narrow, slow, intensify and dematerialise resource loops [ ... ] to minimise resource input into and waste and emission leakage out of the system, improve its operative effectiveness and efficiency and generate competitive advantages" [104] (p. 715).

Against this backdrop, organizational networks are asked to reconsider how and where value is added, consumed, and recovered [106]. In short, the entire value chain and life cycle of a product or service should be designed with a positive two-way relationship between ecological health and abundance that can result in long-term economic growth [34]. However, to overcome the tendency toward business-as-usual and kick-start the CBM, several barriers must be overcome, the main ones of which are legislative, economic, market, financial, global reverse networks, technological, and cultural in nature [51,101,107].

The CBM approach appears suitable for re-thinking the insect feed and food sector in the direction of a CE perspective. Firstly, this is an approach that is well-suited for application to the entire supply chain, from the provision of raw materials to the final consumer, which therefore allows the principles of the CE to be well understood on an operational level, especially concerning sectors such as insect feed and food production, which is facing critical issues in all phases of the supply chain. Secondly, the economic dimension of the CE should be emphasized according to the CBM approach since its adoption is functional to new value creation (at insect farm and supply chain levels).

In our opinion, this holistic approach might represent a useful tool for improving the cost- and eco-effectiveness of insect farming and allows examination of the entire supply chain and the main critical issues that characterize it today. Zucchella and Previtali [25] analyzed a CBM in agriculture, involving different types of innovation, finding a strong collaboration among network members, and showing the role of a focal actor (i.e., network orchestrator) in the implementation and engagement when realizing a circular business model. The focal actor stimulates eco-innovation at the locus of the greatest environmental impacts within a consumption and production system [108]. In this case, the orchestrator "is not a large firm, as in some literature, but coordinates small and large organisations very effectively. Its leadership builds on the transformational leadership of the founders and on the innovativeness and learning advantage of a disruptive technology" [25] (p. 282). This evidence may lead us to think that small businesses can also promote a CSCM model, given that "the global shift from one model of economy to another also concerns smaller companies on a micro-level" [109] (p. 1).

Consumers would also be involved in this perspective since they still represent a weak link due to the skepticism toward the consumption of insect-based food or products fed with insect meal. In this scenario, the crucial role of consumers is evident, as changes in their lifestyles and preferences, partly through their acceptance of radical innovations, such as including insects or their derivatives in their diet or eating animals and fish fed with insects. In this sense, reverse business models could provide the basis of a new economic order focused on the recovery of material flows and sustainable food behavior [28,101,110-112].

As reported above, several authors have begun to study consumer behavior concerning food produced from insect-based foods. More efforts are needed to understand the degree of acceptance of insect-based food and consumer willingness to pay for eating this sort of food. These issues are crucial research topics, useful for better addressing the choices of insect farmers and the entire supply chain. Everyday acts of consumption are some of the most effective levers for change toward a CE.

\section{Conclusions}

This paper provides an overview of the current state of research in insect farming with a focus on economic aspects. In particular, among the various actors that play roles in insect supply chains, attention has focused on one actor for which active participation is crucial in developing CE models 
of insects for feed and food: insect farming. We found that despite the increasing body of research, economic questions persist regarding insect use for food and feed.

We noted some economic research questions that need to be answered in the near future and outlined a conceptual economic approach, the business innovation model, that would allow increasing cost- and eco-effectiveness from a CE perspective.

\section{Some Concluding Remarks Need to Be Done}

To ensure that enterprises embrace a new business model replacing the obsolete one, value must be created for enterprises, clients, and society as a whole [105]. As businesses are not non-profit, they must generate profit, not lose money, while not neglecting the social and environmental pillars of sustainability. The products that they release to the market must be feasible as well as profitable. In this sense, research into the feasibility of using insects as feed and as human food has been conducted, but studies on the costs and profitability of insect farms are lacking. Future studies on insects as feed should better investigate the structure cost and profitability of insect farms, also incorporating case studies that provide the stimulus to other farms to undertake these activities from a CE perspective.

In our opinion, further effort from this perspective is needed, especially on the production of feed for aquaculture because finding sustainable alternatives to fishmeal is urgently required. Several empirical pieces of evidence suggest that insect meal is a valid substitute. Therefore, more economic assessments that can support the sustainable development of this sub-sector are needed.

With regards to consumers, their willingness to include insects or their derivatives in their diet or to eat animals and fish fed with insects was investigated. However, studies aimed at expressly investigating the willingness of consumers to pay for such products are lacking. Future research on consumers must consider economic variables, which could help push farms to embrace this new CE framework. Farms that aim to embrace the opportunity of using the $\mathrm{CE}$ to drive their growth and competitiveness, from a cost-benefit analysis, need to price their products correctly.

Author Contributions: Conceptualization, B.A., R.F., F.A.M., and P.P.; methodology, B.A. and F.A.M.; formal analysis, B.A. and F.A.M.; investigation, B.A. and F.A.M.; writing-original draft preparation, B.A. and F.A.M.; writing-review and editing, B.A., R.F., F.A.M., and P.P.; supervision, R.F. and P.P.; project administration, P.P.; funding acquisition, P.P. All authors have read and agreed to the published version of the manuscript.

Funding: This paper is carried out from the research project "Fine Feed For Fish-4F" granted by the AGER Consortium.

Conflicts of Interest: The authors declare no conflict of interest.

\section{References}

1. FAO. How to Feed the World in 2050. In Proceedings of the Expert Meeting Feed World $205024-26$ June 2009; FAO Hqrs: Rome, Italy.

2. Henchion, M.; Hayes, M.; Mullen, A.M.; Fenelon, M.; Tiwari, B. Future Protein Supply and Demand: Strategies and Factors Influencing a Sustainable Equilibrium. Foods 2017, 6, 53. [CrossRef] [PubMed]

3. Ishangulyyev, R.; Kim, S.; Lee, S.H. Understanding Food Loss and Waste-Why Are We Losing and Wasting Food? Foods 2019, 8, 297. [CrossRef] [PubMed]

4. Roma, R.; Ottomano Palmisano, G.; De Boni, A. Insects as Novel Food: A Consumer Attitude Analysis through the Dominance-Based Rough Set Approach. Foods 2020, 9, 387. [CrossRef] [PubMed]

5. Borrello, M.; Lombardi, A.; Pascucci, S.; Cembalo, L. The seven challenges for transitioning into a bio-based circular economy in the agri-food sector. Recent Pat. Food Nutr. Agric. 2016, 8, 39-47. [CrossRef]

6. Smetana, S.; Palanisamy, M.; Mathys, A.; Heinz, V. Sustainability of insect use for feed and food: Life Cycle Assessment perspective. J. Clean. Prod. 2016, 137, 741-751. [CrossRef]

7. Van Zanten, H.H.; Mollenhorst, H.; Oonincx, D.G.; Bikker, P.; Meerburg, B.G.; de Boer, I.J. From environmental nuisance to environmental opportunity: Housefly larvae convert waste to livestock feed. J. Clean. Prod. 2015, 102, 362-369. [CrossRef] 
8. Henry, M.; Gasco, L.; Piccolo, G.; Fountoulaki, E. Review on the use of insects in the diet of farmed fish: Past and future. Anim. Feed Sci. Technol. 2015, 203, 1-22. [CrossRef]

9. Rumpold, B.A.; Schlüter, O.K. Potential and challenges of insects as an innovative source for food and feed production. Innov. Food Sci. Emerg. Technol. 2013, 17, 1-11. [CrossRef]

10. Banjo, A.; Lawal, O.; Songonuga, E. The nutritional value of fourteen species of edible insects in southwestern Nigeria. Afr. J. Biotechnol. 2006, 5, 298-301.

11. Fasakin, E.; Balogun, A.; Ajayi, O. Evaluation of full-fat and defatted maggot meals in the feeding of clariid catfish Clarias gariepinus fingerlings. Aquac. Res. 2003, 34, 733-738. [CrossRef]

12. Van Huis, A.; Van Itterbeeck, J.; Klunder, H.; Mertens, E.; Halloran, A.; Muir, G.; Vantomme, P. Edible Insects: Future Prospects for Food and Feed Security; Food and Agriculture Organization of the United Nations: Rome, Italy, 2013; ISBN 92-5-107596-4.

13. Govorushko, S. Global status of insects as food and feed source: A review. Trends Food Sci. Technol. 2019, 91, 436-445. [CrossRef]

14. Oonincx, D.G.A.B.; de Boer, I.J.M. Environmental Impact of the Production of Mealworms as a Protein Source for Humans-A Life Cycle Assessment. PLoS ONE 2012, 7, e51145. [CrossRef] [PubMed]

15. Arru, B.; Furesi, R.; Gasco, L.; Madau, F.A.; Pulina, P. The Introduction of Insect Meal into Fish Diet: The First Economic Analysis on European Sea Bass Farming. Sustainability 2019, 11, 1697. [CrossRef]

16. Reverberi, M. Edible insects: Cricket farming and processing as an emerging market. J. Insects Food Feed 2020, 6, 211-220. [CrossRef]

17. Durst, P.B.; Hanboonsong, Y. Small-scale production of edible insects for enhanced food security and rural. J. Insects Food Feed 2015, 1, 25-31. [CrossRef]

18. Gasco, L.; Henry, M.; Piccolo, G.; Marono, S.; Gai, F.; Renna, M.; Lussiana, C.; Antonopoulou, E.; Mola, P.; Chatzifotis, S. Tenebrio molitor meal in diets for European sea bass (Dicentrarchus labrax L.) juveniles: Growth performance, whole body composition and in vivo apparent digestibility. Anim. Feed Sci. Technol. 2016, 220, 34-45. [CrossRef]

19. Alliedmarketresearch. Edible Insects Market by Product Type (Whole Insect, Insect Powder, Insect Meal, Insect Type (Crickets, Black Soldier fly, Mealworms), Application (Animal Feed, Protein Bar and Shakes, Bakery, Confectionery, Beverages)—Global Forecast to 2030. Available online: https://www.researchandmarkets. com/reports/4757400/edible-insects-market-by-product-type-whole. (accessed on 30 June 2020).

20. Kim, T.-K.; Yong, H.I.; Kim, Y.-B.; Kim, H.-W.; Choi, Y.-S. Edible Insects as a Protein Source: A Review of Public Perception, Processing Technology, and Research Trends. Food Sci. Anim. Resour. 2019, $39,521$. [CrossRef]

21. Van Huis, A.; Oonincx, D.G.A.B. The environmental sustainability of insects as food and feed. A review. Agron. Sustain. Dev. 2017, 37. [CrossRef]

22. Gasco, L.; Biancarosa, I.; Liland, N.S. From waste to feed: A review of recent knowledge on insects as producers of protein and fat for animal feeds. Curr. Opin. Green Sustain. Chem 2020. [CrossRef]

23. Chia, S.Y.; Tanga, C.M.; van Loon, J.J.; Dicke, M. Insects for sustainable animal feed: Inclusive business models involving smallholder farmers. Curr. Opin. Environ. Sustain. 2019, 41, 23-30. [CrossRef]

24. Dicke, M. Insects as feed and the Sustainable Development Goals. J. Insects Food Feed 2018, 4, 147-156. [CrossRef]

25. Zucchella, A.; Previtali, P. Circular business models for sustainable development: A "waste is food" restorative ecosystem. Bus. Strategy Environ. 2019, 28, 274-285. [CrossRef]

26. Zielińska, E.; Zieliński, D.; Karaś, M.; Jakubczyk, A. Exploration of consumer acceptance of insects as food in Poland. J. Insects Food Feed 2020. [CrossRef]

27. Caparros Megido, R.C.; Gierts, C.; Blecker, C.; Brostaux, Y.; Haubruge, É.; Alabi, T.; Francis, F. Consumer acceptance of insect-based alternative meat products in Western countries. Food Qual. Prefer. 2016, 52, 237-243. [CrossRef]

28. Imathiu, S. Benefits and food safety concerns associated with consumption of edible insects. NFS J. 2019, 18, 1-11. [CrossRef]

29. Researchandmarkets. Insect Feed Market-Growth, Trends and Forecasts (2020-2025). Available online: https: //www.researchandmarkets.com/reports/4904389/insect-feed-market-growth-trends-and-forecasts (accessed on 30 June 2020). 
30. McDonough, W.; Braungart, M. Cradle to Cradle: Remaking the Way We Make Things; North Point Press: New York, NY, USA, 2010; ISBN 1-4299-7384-6.

31. Gregson, N.; Crang, M.; Fuller, S.; Holmes, H. Interrogating the circular economy: The moral economy of resource recovery in the EU. Econ. Soc. 2015, 44, 218-243. [CrossRef]

32. Zwier, J.; Blok, V.; Lemmens, P.; Geerts, R.-J. The ideal of a zero-waste humanity: Philosophical reflections on the demand for a bio-based economy. J. Agric. Environ. Ethics 2015, 28, 353-374. [CrossRef]

33. Homrich, A.S.; Galvao, G.; Abadia, L.G.; Carvalho, M.M. The circular economy umbrella: Trends and gaps on integrating pathways. J. Clean. Prod. 2018, 175, 525-543. [CrossRef]

34. Korhonen, J.; Nuur, C.; Feldmann, A.; Birkie, S.E. Circular economy as an essentially contested concept. J. Clean. Prod. 2018, 175, 544-552. [CrossRef]

35. Kirchherr, J.; Piscicelli, L.; Bour, R.; Kostense-Smit, E.; Muller, J.; Huibrechtse-Truijens, A.; Hekkert, M. Barriers to the Circular Economy: Evidence From the European Union (EU). Ecol. Econ. 2018, 150, $264-272$. [CrossRef]

36. Stevenson, R.S.; Evans, J.W. Editorial to: Cutting across interests: Cleaner production, the unified force of sustainable development. J. Clean. Prod. 2004, 3, 185-187. [CrossRef]

37. Graedel, T.; Allenby, B.R. Industrial Ecology and Sustainable Engineering: International Edition; Pearson Education Inc.: London, UK; Prentice Hall: Upper Saddle River, NY, USA, 2010.

38. Ayres, R.U. Industrial metabolism and global change. Int. Soc. Sci. J. 1989, 121, 363-373.

39. Commoner, B. The Closing Circle-Nature, Man \& Technology da Barry Commoner: VERY GOOD Paperback| Free Shipping Books; Random House Inc.: New York, NY, USA, 1971.

40. Lyle, J.T. Regenerative Design for Sustainable Development; John Wiley \& Sons: Hoboken, NJ, USA, 1996; ISBN 0-471-17843-8.

41. Benyus, J.M. Biomimicry: Innovation Inspired by Nature; Harper Perennial: New York, NY, USA, 1997.

42. Pauli, G.A. The Blue Economy: 10 Years, 100 Innovations, 100 Million Jobs; Paradigm Publications: New Mexico, NM, USA, 2010; ISBN 0-912111-90-9.

43. Lovins, A.B.; Lovins, L.H.; Hawken, P. A Road Map for Natural Capitalism Harvard Business Review, 1-14 (HBR paperback reprint 2000). 1999.

44. Haupt, M.; Vadenbo, C.; Hellweg, S. Do We Have the Right Performance Indicators for the Circular Economy?: Insight into the Swiss Waste Management System. J. Ind. Ecol. 2017, 21, 615-627. [CrossRef]

45. Singh, J.; Ordoñez, I. Resource recovery from post-consumer waste: Important lessons for the upcoming circular economy. J. Clean. Prod. 2016, 134, 342-353. [CrossRef]

46. Heyes, G.; Sharmina, M.; Mendoza, J.M.F.; Gallego-Schmid, A.; Azapagic, A. Developing and implementing circular economy business models in service-oriented technology companies. J. Clean. Prod. 2018, 177, 621-632. [CrossRef]

47. Ma, S.; Wen, Z.; Chen, J.; Wen, Z. Mode of circular economy in China's iron and steel industry: A case study in Wu'an city. J. Clean. Prod. 2014, 64, 505-512. [CrossRef]

48. Yuan, Z.; Bi, J.; Moriguichi, Y. The circular economy: A new development strategy in China. J. Ind. Ecol. 2006, 10, 4-8. [CrossRef]

49. Jabbour, C.J.C.; de Sousa Jabbour, A.B.L.; Sarkis, J.; Filho, M.G. Unlocking the circular economy through new business models based on large-scale data: An integrative framework and research agenda. Technol. Forecast. Soc. Chang. 2019, 144, 546-552. [CrossRef]

50. Gallaud, D.; Laperche, B. Circular Economy, Industrial Ecology and Short Supply Chain; John Wiley \& Sons: Hoboken, NJ, USA, 2016; ISBN 978-1-119-30746-4.

51. Ghisellini, P.; Ulgiati, S. Circular economy transition in Italy. Achievements, perspectives and constraints. J. Clean. Prod. 2020, 243, 118360. [CrossRef]

52. Pearson Peter, J. Energy Transitions. In The New Palgrave Dictionary of Economics; Palgrave Macmillan: London, UK, 2016.

53. Geels, F.W. Technological transitions as evolutionary reconfiguration processes: A multi-level perspective and a case-study. Res. Policy 2002, 31, 1257-1274. [CrossRef]

54. Geels, F.W.; Schot, J. Typology of sociotechnical transition pathways. Res. Policy 2007, 36, 399-417. [CrossRef]

55. Corvellec, H.; Böhm, S.; Stowell, A.; Valenzuela, F. Introduction to the special issue on the contested realities of the circular economy. Cult. Organ. 2020, 26, 97-102. [CrossRef] 
56. Sufian, A.; Chandra, U.; Das, S.; Chettri, D. Advancements in Agriculture Strategies and Environmental Impact: A Review; Social Science Research Network: Rochester, NY, USA, 2020.

57. Wang, B.; Dong, F.; Chen, M.; Zhu, J.; Tan, J.; Fu, X.; Wang, Y.; Chen, S. Advances in Recycling and Utilization of Agricultural Wastes in China: Based on Environmental Risk, Crucial Pathways, Influencing Factors, Policy Mechanism. Procedia Environ. Sci. 2016, 31, 12-17. [CrossRef]

58. Graedel, T.E.; Allenby, B.R. Robert A. Laudise 1930-1998. J. Ind. Ecol. 1998, 2, 13-14. [CrossRef]

59. Drucker, P.F. Managing for business effectiveness. Harvard Business Review 1963, 41, 53-60.

60. EMF Ellen MacArthur Foundation. Available online: https://www.ellenmacarthurfoundation.org (accessed on 2 June 2020).

61. Ghisellini, P.; Cialani, C.; Ulgiati, S. A review on circular economy: The expected transition to a balanced interplay of environmental and economic systems. J. Clean. Prod. 2016, 114, 11-32. [CrossRef]

62. Kirchherr, J.; Reike, D.; Hekkert, M. Conceptualizing the circular economy: An analysis of 114 definitions. Resour. Conserv. Recycl. 2017, 127, 221-232. [CrossRef]

63. European Commission. Closing the Loop-An EU Action Plan for the Circular Economy; COM (2015) 614 final; 2015; Available online: https://www.eea.europa.eu/policy-documents/com-2015-0614-final (accessed on 30 June 2020).

64. Schroeder, P.; Anggraeni, K.; Weber, U. The Relevance of Circular Economy Practices to the Sustainable Development Goals. J. Ind. Ecol. 2019, 23, 77-95. [CrossRef]

65. Millar, N.; McLaughlin, E.; Börger, T. The circular economy: Swings and roundabouts? Ecol. Econ. 2019, 158, 11-19. [CrossRef]

66. Tao, J.; Li, Y.O. Edible insects as a means to address global malnutrition and food insecurity issues. Food Qual. Saf. 2018, 2, 17-26. [CrossRef]

67. Yen, A.L. Insects as food and feed in the Asia Pacific region: Current perspectives and future directions. J. Insects Food Feed 2015, 1, 33-55. [CrossRef]

68. Van Huis, A. Edible insects contributing to food security? Agric. Food Secur. 2015, 4, 20. [CrossRef]

69. Van Huis, A. Potential of insects as food and feed in assuring food security. Annu. Rev. Entomol. 2013, 58, 563-583. [CrossRef] [PubMed]

70. Wilson, R. Small Animals for Small Farms; Diversification booklet number 14; FAO: Rome, Italy, 2012.

71. Mlcek, J.; Rop, O.; Borkovcova, M.; Bednarova, M. A comprehensive look at the possibilities of edible insects as food in Europe-a review. Pol. J. Food Nutr. Sci. 2014, 64, 147-157. [CrossRef]

72. Cortes Ortiz, J.A.; Ruiz, A.T.; Morales-Ramos, J.A.; Thomas, M.; Rojas, M.G.; Tomberlin, J.K.; Yi, L.; Han, R.; Giroud, L.; Jullien, R.L. Chapter 6-Insect Mass Production Technologies. In Insects as Sustainable Food Ingredients; Dossey, A.T., Morales-Ramos, J.A., Rojas, M.G., Eds.; Academic Press: San Diego, CA, USA, 2016; pp. 153-201. ISBN 978-0-12-802856-8.

73. Dossey, A.T.; Tatum, J.T.; McGill, W.L. Modern Insect-Based Food Industry: Current Status, Insect Processing Technology, and Recommendations Moving Forward. In Insects as Sustainable Food Ingredients; Dossey, A.T., Morales-Ramos, J.A., Rojas, M.G., Eds.; Academic Press: San Diego, CA, USA, 2016; pp. 113-152. ISBN 978-0-12-802856-8.

74. Derrien, C.; Boccuni, A. Current status of the insect producing industry in Europe. In Edible Insects in Sustainable Food Systems; Springer: Berlin/Heidelberg, Germany, 2018; pp. 471-479.

75. Diener, S.; Solano, N.M.S.; Gutiérrez, F.R.; Zurbrügg, C.; Tockner, K. Biological treatment of municipal organic waste using black soldier fly larvae. Waste Biomass Valorization 2011, 2, 357-363. [CrossRef]

76. Diener, S.; Zurbrügg, C.; Tockner, K. Conversion of organic material by black soldier fly larvae: Establishing optimal feeding rates. Waste Manag. Res. 2009, 27, 603-610. [CrossRef]

77. Collins, C.M.; Vaskou, P.; Kountouris, Y. Insect food products in the Western world: Assessing the potential of a new 'green'market. Ann. Entomol. Soc. Am. 2019, 112, 518-528. [CrossRef]

78. Mordor Intelligence. Insect Feed Market—Growth, Trends and Forecasts (2020-2025). 2019. Available online: https://www.mordorintelligence.com/industry-reports/insect-feed-market (accessed on 30 June 2020).

79. Gahukar, R. Edible insects farming: Efficiency and impact on family livelihood, food security, and environment compared with livestock and crops. In Insects as Sustainable Food Ingredients; Elsevier: Amsterdam, The Netherlands, 2016; pp. 85-111.

80. Onsongo, V.; Osuga, I.M.; Gachuiri, C.; Wachira, A.; Miano, D.; Tanga, C.; Ekesi, S.; Nakimbugwe, D.; Fiaboe, K. Insects for income generation through animal feed: Effect of dietary replacement of soybean and 
fish meal with black soldier fly meal on broiler growth and economic performance. J. Econ. Entomol. 2018, 111, 1966-1973. [CrossRef]

81. Borrello, M.; Caracciolo, F.; Lombardi, A.; Pascucci, S.; Cembalo, L. Consumers' Perspective on Circular Economy Strategy for Reducing Food Waste. Sustainability 2017, 9, 141. [CrossRef]

82. Caparros Megido, R.; Sablon, L.; Geuens, M.; Brostaux, Y.; Alabi, T.; Blecker, C.; Drugmand, D.; Haubruge, É.; Francis, F. Edible Insects Acceptance by B elgian Consumers: Promising Attitude for Entomophagy Development. J. Sens. Stud. 2014, 29, 14-20. [CrossRef]

83. Hartmann, C.; Shi, J.; Giusto, A.; Siegrist, M. The psychology of eating insects: A cross-cultural comparison between Germany and China. Food Qual. Prefer. 2015, 44, 148-156. [CrossRef]

84. Hartmann, C.; Siegrist, M. Consumer perception and behaviour regarding sustainable protein consumption: A systematic review. Trends Food Sci. Technol. 2017, 61, 11-25. [CrossRef]

85. House, J. Consumer acceptance of insect-based foods in the Netherlands: Academic and commercial implications. Appetite 2016, 107, 47-58. [CrossRef]

86. Tan, H.S.G. Eating Insects: Consumer Acceptance of a Culturally Inappropriate Food; Wageningen University: Wageningen, The Netherlands, 2017.

87. Tani, Y.; Hashimoto, S.; Ochiai, M. What makes rural, traditional, cultures more sustainable? Implications from conservation efforts in mountainous rural communities of Japan. Landsc. Res. 2016, 41, 892-905. [CrossRef]

88. Verbeke, W. Profiling consumers who are ready to adopt insects as a meat substitute in a Western society. Food Qual. Prefer. 2015, 39, 147-155. [CrossRef]

89. Schlup, Y.; Brunner, T. Prospects for insects as food in Switzerland: A tobit regression. Food Qual. Prefer. 2018, 64, 37-46. [CrossRef]

90. Mancini, S.; Sogari, G.; Menozzi, D.; Nuvoloni, R.; Torracca, B.; Moruzzo, R.; Paci, G. Factors predicting the intention of eating an insect-based product. Foods 2019, 8, 270. [CrossRef]

91. FAO, Food. Agriculture Organization of the United Nations (2012); FAOSTATS: Rome, Italy, 2012.

92. Herrero, M.; Henderson, B.; Havlík, P.; Thornton, P.K.; Conant, R.T.; Smith, P.; Wirsenius, S.; Hristov, A.N.; Gerber, P.; Gill, M. Greenhouse gas mitigation potentials in the livestock sector. Nat. Clim. Chang. 2016, 6, 452-461. [CrossRef]

93. Premalatha, M.; Abbasi, T.; Abbasi, T.; Abbasi, S. Energy-efficient food production to reduce global warming and ecodegradation: The use of edible insects. Renew. Sustain. Energy Rev. 2011, 15, 4357-4360. [CrossRef]

94. Ramos-Elorduy, J.; González, E.A.; Hernández, A.R.; Pino, J.M. Use of Tenebrio molitor (Coleoptera: Tenebrionidae) to recycle organic wastes and as feed for broiler chickens. J. Econ. Entomol. 2002, 95, 214-220. [CrossRef] [PubMed]

95. Roffeis, M.; Wakefield, M.E.; Almeida, J.; Valada, T.R.A.; Devic, E.; Kenis, M.; Nacambo, S.; Fitches, E.C.; Koko, G.K.; Mathijs, E. Life cycle cost assessment of insect based feed production in West Africa. J. Clean. Prod. 2018, 199, 792-806. [CrossRef]

96. Sogari, G.; Amato, M.; Biasato, I.; Chiesa, S.; Gasco, L. The Potential Role of Insects as Feed: A Multi-Perspective Review. Animals 2019, 9, 119. [CrossRef] [PubMed]

97. Kagata, H.; Ohgushi, T. Positive and negative impacts of insect frass quality on soil nitrogen availability and plant growth. Popul. Ecol. 2012, 54, 75-82. [CrossRef]

98. Mutsakatira, E.; Buckley, C.; Mercer, S.J. Potential Use of the Black Soldier Fly Larvae in Faecal Sludge Management: A Study in Durban, South Africa, In Proceedings of the 41st WEDC International Conference; Paper 2994. Shaw, R.J., Ed.; WEDC Loughborough University: Nakuru, Kenya, 2018.

99. Westhoek, H.; Rood, G.; van den Berg, M.; Janse, J.; Nijdam, D.; Reudink, M.; Stehfest, E. The protein puzzle: The consumption and production of meat, dairy and fish in the European Union. Eur. J. Nutr. Food Saf. 2011, 4, 123-144.

100. Linder, M.; Williander, M. Circular Business Model Innovation: Inherent Uncertainties. Bus. Strategy Environ. 2017, 26, 182-196. [CrossRef]

101. Planing, P. Business model innovation in a circular economy reasons for non-acceptance of circular business models. Open J. Bus. Model Innov. 2015, 1, 1-11.

102. Hsieh, C.; Nickerson, J.A.; Zenger, T.R. Opportunity discovery, problem solving and a theory of the entrepreneurial firm. J. Manag. Stud. 2007, 44, 1255-1277. [CrossRef] 
103. Nußholz, J.L. Circular business models: Defining a concept and framing an emerging research field. Sustainability 2017, 9, 1810. [CrossRef]

104. Geissdoerfer, M.; Morioka, S.N.; de Carvalho, M.M.; Evans, S. Business models and supply chains for the circular economy. J. Clean. Prod. 2018, 190, 712-721. [CrossRef]

105. Osterwalder, A.; Pigneur, Y. Business Model Generation: A Handbook for Visionaries, Game Changers, and Challengers; John Wiley \& Sons: Hoboken, NJ, USA, 2010; ISBN 978-0-470-87641-1.

106. Barber, K.D.; Beach, R.; Zolkiewski, J. Environmental sustainability: A value cycle research agenda. Prod. Plan. Control 2012, 23, 105-119. [CrossRef]

107. Bosman, R.; Rotmans, J. Transition Governance towards a Bioeconomy: A Comparison of Finland and The Netherlands. Sustainability 2016, 8, 1017. [CrossRef]

108. Dewick, P.; Foster, C. Focal Organisations and Eco-innovation in Consumption and Production Systems. Ecol. Econ. 2018, 143, 161-169. [CrossRef]

109. Lewandowski, M. Designing the Business Models for Circular Economy-Towards the Conceptual Framework. Sustainability 2016, 8, 43. [CrossRef]

110. Orsi, L.; Voege, L.L.; Stranieri, S. Eating edible insects as sustainable food? Exploring the determinants of consumer acceptance in Germany. Food Res. Int. 2019, 125, 108573. [CrossRef]

111. Verbeke, W.; Spranghers, T.; De Clercq, P.; De Smet, S.; Sas, B.; Eeckhout, M. Insects in animal feed: Acceptance and its determinants among farmers, agriculture sector stakeholders and citizens. Anim. Feed Sci. Technol. 2015, 204, 72-87. [CrossRef]

112. Iannuzzi, E.; Sisto, R.; Nigro, C. The willingness to consume insect-based food: An empirical research on Italian consumers. Agric. Econ. 2019, 65, 454-462. [CrossRef]

(C) 2020 by the authors. Licensee MDPI, Basel, Switzerland. This article is an open access article distributed under the terms and conditions of the Creative Commons Attribution (CC BY) license (http://creativecommons.org/licenses/by/4.0/). 